\title{
Analisis Pengaruh Indeks Pembangunan Manusia, Jumlah Pengangguran, dan Jumlah Penduduk Terhadap Jumlah Penduduk Miskin di Sulawesi Selatan pada Tahun 2019
}

\author{
Rahma Darja \\ Universitas Islam Negeri Alauddin Makassar, rahmahdarja99@gmail.com \\ Ilham Syata \\ Universitas Islam Negeri Alauddin Makassar, ilham.syata@uin-alauddin.ac.id
}

\begin{abstract}
ABSTRAK, Tujuan penelitian ini adalah untuk mengetahui pengaruh Indeks Pembangunan Manusia (X1), Jumlah Pengangguran (X2) dan Jumlah Penduduk (X3) terhadap Jumlah Penduduk Miskin (Y) di Sulawesi Selatan tahun 2019. Penelitian ini menggunakan analisis regresi berganda dengan melakukan pendugaan model, uji hipotesis, menentukan model terbaik, uji asumsi, dan menghitung koefisien determinasi. Hasil penelitian ini menunjukkan Indeks Pembangunan Manusia (X1) berpengaruh negatif terhadap Jumlah Penduduk Miskin (Y), jumlah pengangguran (X2) tidak berpengaruh terhdap Penduduk Miskin (Y), dan Jumlah Penduduk (X3) berpengaruh positif terhadap Penduduk Miskin (Y). Berdasarkan model terbaik diperoleh pengaruh Indeks Pembangunan Manusia (X1) dan Jumlah Penduduk (X3) terhadap Jumlah Penduduk Miskin (Y) sebesar 75,63\%.
\end{abstract}

Kata Kunci: analisis regresi, penduduk miskin

\section{PENDAhuluan}

Di Indonesia kemiskinan terjadi diberbagai daerah, salah satunya di Provinsi Sulawesi Selatan. Berdasarkan hasil survey sosial ekonomi oleh Badan Pusat Statistik (BPS) tercatat jumlah penduduk miskin di Provinsi Sulawesi Selatan pada tahun 2015 yaitu 797,720, tahun 2016 yaitu 807,030 jiwa, tahun 2017 yaitu 813,070 jiwa, tahun 2018 yaitu 792,630 jiwa, dan tahun 2019 yaitu 767,800 jiwa. Peningkatan jumlah penduduk miskin terjadi pada tahun 2015 sampai tahun 2017, sedangkan terjadi penurunan pada tahun 2018 sampai tahun 2019.

Peningkatan jumlah penduduk miskin di Provinsi Sulawesi Selatan disebabkan oleh berbagai faktor [1], seperti terjadinya krisis ekonomi, indeks pembangunan manusia, pertambahan jumlah penduduk tiap tahun, pengaruh kebijakan pemerintah, banyak jumlah pengangguran, dan sebagainya. Pertumbuhan penduduk yang pesat menyebabkan tingkat kesejahteraan masyarakat tidak mengalami perbaikan dan dalam jangka panjang akan mengalami penurunan kesejahteraan serta meningkatkan jumlah penduduk miskin.

Pencapaian kualitas manusia dapat diukur dengan Indeks Pembanguan Manusia (IPM). Rendahnya Indeks Pembangunan Manusia (IPM) akan mengakibatkan rendahnya produktivitas kerja dari penduduk [1]. Produktivitas yang rendah akan mengakibatkan rendanya perolehan pendapatan, sehingga menyebabkan tingginya jumlah penduduk miskin. Pengangguran memiliki hubungan yang sangat erat dalam mempengaruhi tingkat kemiskinan. Pengangguran yang tinggi akan menyebabkan pendapatan berkurang, sehingga tidak dapat memenuhi kebutuhan sehari-hari yang pada akhirnya akan mengalami kemiskinan. Oleh karena itu, dalam analisis regresi akan diuji pengaruh jumlah penduduk, indeks pembangunan manusia dan tingkat pengangguran terhadap jumlah penduduk miskin dengan analisis regresi[2,4,5]. Tujuan penelitian ini adalah untuk mengetahui Pengaruh Indeks Pembangunan Manusia, Pengangguran dan Jumlah Penduduk Terhadap jumlah Penduduk Miskin Di Sulawesi Selatan Tahun 2019.

\section{TINJAUAN PUSTAKA}

\section{Analisis Regresi}

Dalam ilmu statistika, teknik yang umum digunakan untuk menganalisis hubungan antara dua atau lebih variabel adalah analisis regresi. Analisis regresi (regression analysis) merupakan suatu teknik (technique) untuk membangun persamaan garis lurus dan menggunakan persamaan tersebut untuk membuat perkiraan (prediction) $[2,3,4,5,6]$.

Model matematis dalam menjelaskan hubungan antarvariabel dalam analisis regresi 
menggunakan persamaan regresi. Persamaan regresi (regression equation) adalah suatu persamaan matematis yang mendefinisikan hubungan antara dua variabel [7].

Dalam suatu persamaan regresi terdapat dua macam variabel, yaitu variabel dependen (dependent variable) dan variabel independen (independent variable) [4,5,7]. Variabel dependen adalah variabel yang nilainya bergantung dari nilai variabel lain dan variabel independen adalah variabel yang nilainya tidak bergantung dari variabel lain. Dengan menggunakan persamaan regresi ini variabel dependen ditaksir berdasarkan pada nilai variabel dependen tertentu.

\section{Analisis Regresi Linear Sederhana}

Analisis regresi linear sederhana adalah metode statistik yang berfungsi untuk menguji sejauh mana hubungan sebab akibat antara variabel faktor penyebab $(\mathrm{X})$ terhadap variabel akibatnya $[4,5,7]$. Faktor penyebab pada umumnya dilambangkan dengan $\mathrm{X}$ atau disebut juga dengan Predictor sedangkan variabel akibat dilambangkan dengan $\mathrm{Y}$ atau disebut juga dengan response.

\section{Analisis Regresi Linear Berganda}

Analisis regresi linear berganda digunakan untuk memprediksi berubahnya nilai variabel tertentu bila variabel lain berubah. Dikatakan regresi berganda, karena jumlah variabel bebas (independen) sebagai prediktor lebih dari satu, maka digunakan persamaan regresi linier berganda.

Bentuk umum model regresi linier berganda $[1,2,3,4,5,6]$ adalah

$$
Y=\beta_{0}+\beta_{1} X_{1}+\cdots+\beta_{k} X_{k}+\varepsilon
$$

Dimana,

$Y \quad=$ Variabel dependen

$X_{1}, X_{2}, \ldots, X_{k}=$ Variabel independen

$\varepsilon \quad=$ Galat acak

$\beta_{0}, \beta_{1}, \ldots, \beta_{k}=$ Parameter populasi yang nilainya tidak diketahui

Variabel independen $X_{1}, X_{2}, \ldots, X_{k}$ dianggap bukan variabel acak dan dapat diobservasi dengan kekeliruan yang diabaikan.

\section{Asumsi Analisis Regresi}

a. Uji Normalitas

Salah satu asumsi klasik adalah uji normalitas yaitu asumsi yang menyatakan bahwa sisaan $e_{i}$ berdistribusi normal. Untuk mengetahui persamaan regresi tersebut sisaan $e_{i}$ berdistribusi normal dapat dilakukan dengan normal P-P plot atau uji kolmogorof-smirnov.[4,5,7]

Hipotesis yang diuji adalah :

$H_{0}=$ sisaan berdistribusi normal

$H_{1}=$ sisaan tidak berdistribusi normal

\section{b. Uji Heteroskedastisitas}

Salah satu asumsi klasik adalah uji heteroskedastisitas yaitu asumsi yang menyatakan bahwa varian setiap sisaan $\left(e_{i}\right)$ masih tetap sama baik untuk nilai-nilai pada variabel independen yang kecil maupun besar [4,5,7]. Asumsi ini dapat ditulis sebagai berikut :

$$
\operatorname{var}\left(e_{i}\right)=\sigma^{2}, i=1,2, \ldots, n
$$

Hipotesis yang diuji adalah :

$H_{0}=$ tidak terjadi heteroskedastisitas

$H_{1}=$ terjadi heteroskedastisitas

\section{c. Uji Autokorelasi}

Salah satu asumsi penting dari regresi linear adalah bahwa tidak ada autokorelasi antara serangkaian pengamatan yang diurutkan berdasarkan waktu. Pengujian secara empiris dilakukan dengan menggunakan statistik uji Durbin Watson [4,5]. Hipotesis yang diuji adalah :

$H_{0}=$ tidak terdapat autokorelasi antar sisaan

$H_{1}=$ terdapat autokorelasi antar sisaan

Mekanisme uji Durbin Watson adalah :

1) mengestimasi model regresi dengan metode kuadrat terkecil untuk memperoleh nilai $e_{i}$

2) mencari nilai $d$ yang diperoleh dengan rumus :

$$
d=\frac{\sum_{i-2}^{n}\left(e_{i}-e_{i-1}\right)^{2}}{\sum_{i-1}^{n} e_{i}^{2}}
$$

Dimana,

$$
\begin{array}{ll}
e_{i} & =\text { sisaan ke } \mathrm{i} \\
n & =\text { Banyak data } \\
d & =\text { nilai Durbin Watson }
\end{array}
$$


3) untuk ukuran sampel dan banyaknya variabel tertentu dapat dilihat pada tabel Durbin Watson adalah:

a) jika $d<d_{L}$ atau $d>d_{L}$, maka $H_{0}$ ditolak artinya terjadi autokorelasi.

b) jika $d_{U}<d<4-d_{U}$, maka $H_{0}$ diterima artinya tidak terdapat autokorelasi.

c) Jika $\quad d_{L} \leq d \leq d_{U}$ atau $4-d_{U} \leq$ $d \leq 4-d_{L}$, maka tidak dapat diputuskan apakah $H_{0}$ diterima atau ditolak, sehingga tidak dapat disimpulkan ada tidaknya autokorelasi. [4,5,7]

\section{d. Uji Multikolinearitas}

Kolinearitas terjadi karena terdapat korelasi yang cukup tinggi diantara variabel independen VIF (Variance Inflation Factor) merupakan salah satu cara untuk mengukur besar kolinearitas dan didefiniskan sebagai berikut :

$$
V I F=\frac{1}{1-R_{j}^{2}}
$$

Dimana,

$R_{j}^{2}=$ Koefisien determinasi antara $X_{j}$ dengan variabel bebas lainnya pada model.

$$
\begin{array}{ll}
n & =\text { Banyak data } \\
d & =\text { nilai Durbin Watson } \\
{[4,5,7]} &
\end{array}
$$

Hipotesis yang diuji adalah :

$H_{0}=$ tidak terjadi multikolinearitas

$H_{1}=$ terjadi multikolinearitas

\section{Uji Koefisien Regresi Linear Berganda}

Pengujian koefisien regresi bertujuan untuk mengetahui ada atau tidaknya pengaruh variabel terhadap variabel tidak bebas, baik secara serentak maupun secara parsial.

\section{a. Uji Simultan (Uji F)}

Penggunaan Uji-F bertujuan mengetahui apakah variabel-variabel babes $\left(X_{1}\right.$ dan $\left.X_{2}\right)$ secara signifikan bersama-sama berpengaruh terhadap variabel tak bebas $\mathrm{Y}$ $[4,5,7]$.

Tahapan yang dilakukan dalam Uji-F adalah:
1. Menentukan Hipotesis

$H_{0}: \beta_{1}=\beta_{2}=0 ;\left(\right.$ variabel $X_{1}$ dan $X_{2}$ tidak berpengaruh terhadap Y).

$H_{1}: \beta_{1} \neq \beta_{2} \neq 0$; (variabel $X_{1}$ dan $X_{2}$ berpengaruh terhadap Y).

2. Menetukan Taraf/Tingkat Signifikansi $(\alpha)$

Nilai yang sering digunakan untuk addalah $\alpha=5 \%$

3. Menentukan F hitung

Rumus F hitung:

$$
F=\frac{r^{2}(n-k-1)}{k\left(1-r^{2}\right)}
$$

Dimana

$$
\begin{array}{ll}
r^{2} & =\text { Koefisien determinasi } \\
n & =\text { Banyak data } \\
k & =\text { Banyak variabel bebas }
\end{array}
$$

4. Menentukan $\mathrm{F}$ table (mempergunakan table Uji-F)

Table Uji-F untuk $\alpha=5 \%$ dengan derajat kebebasan pembilang (Numerator, df) $=\mathrm{k}-1$; dan untuk penyebut (Denominator, $\mathrm{df})=\mathrm{n}-\mathrm{k} \cdot \mathrm{n}=$ jumlah sample/pengukuran, $\mathrm{k}=$ jumlah variabel bebas dan terikat.

5. Kriteria Pengujian Nilai $F_{\text {hit }}$ dan $F_{t a b}$ Apabila nilai $F_{\text {hit }}<F_{t a b}$, maka hipotesis $H_{1}$ ditolak dan $H_{0}$ diterima.

Apabila nilai $F_{\text {hit }}>F_{t a b}$, maka hipotesis $H_{1}$ diterima dan $H_{0}$ ditolak.

6. Kesimpulan : akan disimpulkan apakah ada/tidak pengaruh variabel-variabel bebas $\left(X_{1}\right.$ dan $\left.X_{2}\right)$ terhadap variabel tak bebas $(\mathrm{Y})$.

\section{b. Uji Parsial (Uji t)}

Pengujian koefisien regresi secara parsial bertujuan mengetahui apakah persamaan model regresi yang terbentuk secara parsial variabel-variabel bebasnya $\left(X_{1}\right.$ dan $\left.X_{2}\right)$ berpengaruh signifikan terhadap variabel tak bebas (Y). [4,5,7]

Tahapan dalam melakukan Uji-t adalah:

1. Menentukan Hipotesis $H_{0}: \beta=0$; variabel $\mathrm{X}$ tidak berpengaruh signifikan/nyata terhadap $\mathrm{Y}$.

$H_{1}: \beta \neq 0 ;$ variabel $\mathrm{X}$ berpengaruh signifikan/nyata terhadap $\mathrm{Y}$. 
2. Menentukan Tingkat Signifikansi $(\alpha)$. Tingkat signifikansi, $\alpha$ yang sering digunakan adalah $\alpha=5 \%(\alpha=0,05)$

3. Menentukan nilai t hitung menggunakan rumus:

$$
t=\frac{r \sqrt{n-2}}{\sqrt{1-r^{2}}}
$$

Dimana

$$
\begin{array}{ll}
\mathrm{r} & =\text { Koefisien korelasi sederhana } \\
n & =\text { Banyak data }
\end{array}
$$

4. Menentukan daerah penolakan $H_{0}$ (daerah kritis)

Bentuk pengujian dua arah, sehingga menggunakan uji-t dua arah:

$H_{0}$ akan ditolak jika $t_{h i t}>t_{t a b}$ atau $-\left(t_{\text {hit }}\right)<-\left(t_{t a b}\right)$, berarti $H_{1}$ diterima.

$H_{0}$ akan diterima jika $-\left(t_{\text {hit }}\right)<t_{t a b}<$ $t_{\text {hit }}$, berarti $H_{1}$ ditolak.

5. Menentukan $\mathrm{t}$ table (mempergunakan table Uji-t)

Table Uji-t untuk $\alpha=5 \%$ dan derajat kebebasan (df) $=\mathrm{n}-\mathrm{k} ;(\mathrm{n}=$ jumlah sampel/pengukuran, $\mathrm{k}$ adalah jumlah variabel (variabel bebas + variabel terikat).

6. Kriteria Pengujian nilai $\mathrm{t}$ hitung dan $\mathrm{t}$ table

Bila nilai $t_{\text {hit }}<t_{t a b}$, maka $H_{0}$ diterima $H_{1}$ ditolak.

Bila nilai $t_{\text {hit }}>t_{t a b}$, maka $H_{0}$ ditolak $H_{1}$ diterima.

7. Kesimpulan hasil uji signifikansi

\section{Koefisien Determinasi $\left(R^{2}\right)$}

a. Untuk mengetahui persentase pengaruh variabel bebas $X_{1}$ dan $X_{2}$ terhadap variabel terikat $\mathrm{Y}$ digunakan koefisien determinasi

b. Besarnya $R^{2}$ dihitung dengan rumus:

\section{Dimana}

$$
R^{2}=\frac{\left(b_{1} \sum X_{1} Y\right)+\left(b_{2} \sum X_{2} Y\right)}{\sum Y^{2}}
$$

$$
\begin{aligned}
& b_{1}=\frac{\left(\sum X_{1} Y\right)\left(\sum X_{2}{ }^{2}\right)-\left(\sum X_{2} Y\right)\left(\sum X_{1} X_{2}\right)}{\left(\sum X_{1}^{2}\right)\left(\sum X_{2}^{2}\right)-\left(\sum X_{1} X_{2}\right)^{2}} \\
& b_{2}=\frac{\left(\sum X_{2} Y\right)\left(\sum X_{1}^{2}\right)-\left(\sum X_{1} Y\right)\left(\sum X_{1} X_{2}\right)}{\left(\sum X_{1}{ }^{2}\right)\left(\sum X_{2}{ }^{2}\right)-\left(\sum X_{1} X_{2}\right)^{2}}
\end{aligned}
$$

c. Apabila $R^{2}$ bernilai 0 , maka dalam model persamaan regresi yang terbentuk, variasi variabel tak bebas $\mathrm{Y}$ tidak sedikitpun dapat dijelaskan oleh variasi variabel-variabel bebas $X_{1}$ dan $X_{2}$

d. Apabila $R^{2}$ bernilai 1, maka dalam model persamaan regresi yang terbentuk, variabel tak bebas $Y$ secara sempurna dapat dijelaskan oleh variasi variabel-variabel bebas $X_{1}$ dan $X_{2}$. [4,5,7]

\section{Hipotesis}

Adapun hipotesis pada penelitian ini adalah :

$H_{1}=$ Terdapat pengaruh yang signifikan antara Indeks Pembangunan Manusia dengan Jumlah Penduduk Miskin.

$\mathrm{H}_{2}=$ Terdapat pengaruh yang signifikan antara Pengangguran Terbuka dengan Jumlah Penduduk Miskin.

$H_{3}=$ Terdapat pengaruh yang signifikan antara Jumlah Penduduk dengan Jumlah Penduduk Miskin.

$H_{4}=$ Semua variabel berpengaruh secara signifikan terhadap Jumlah Penduduk Miskin.

\section{Jenis Penelitian}

\section{METODOLOGI}

Jenis penelitian yang digunakan pada penelitian ini adalah jenis penelitian Terapan.

\section{Jenis dan Sumber Data}

Data yang digunakan dalam penelitian ini adalah data sekunder yang diperolah dari Website Badan Pusat Statistik (BPS).

\section{Variabel dan Definisi Operasional Variabel}

Variabel yang digunakan pada penelitian ini adalah Indeks Pembangunan Manusia (X1), Pengangguran Terbuka (X2), Jumlah Penduduk (X3) dan Jumlah Penduduk Miskin (Y).

Adapun definisi operasional variabel yang digunakan dalam penelitan ini adalah sebagai berikut :

1. Indeks Pembangunan Manusia (X1) adalah indikator yang menjelaskan bagaimana penduduk suatu wilayah mempunyai kesempatan untuk mengakses hasil dari suatu pembangunan sebagai bagian dari haknya dalam memperoleh pendapatan, kesehatan, pendidikan, dan sebagainya. 
2. Pengangguran Terbuka (X2) adalah penduduk dalam angkatan kerja yang tidak memiliki pekerjaan atau sedang mencari perkerjaan di Sulawesi Selatan pada tahun 2019.

3. Jumlah Penduduk (X3) adalah banyaknya penduduk di Sulawesi Selatan pada tahun 2019.

4. Jumlah Penduduk Miskin (Y) adalah persentase keselurahan penduduk miskin di masing-masing kabupaten di Sulawesi Selatan pada tahun 2019.

\section{Prosedur Penelitian}

Penelitian ini menggunakan metode kuantitatif dengan studi yang diterapkan adalah analisis regresi linear berganda yang menggunakan data setiap Kabupaten di Sulawesi Selatan pada tahun 2019. Adapun analisis data adalah sebagai berikut :

1. Analisis Regresi Linear Berganda

Analisis yang memliki variabel bebas lebih dari satu disebut regresi linear berganda. Analisis regresi berganda digunakan untuk melihat ada atau tidaknya pengaruh signifikan dua atau lebih variabel independen terhadap variabel dependennya. Model yang digunakan dalam penelitian ini dijabarkan dalam fungsi sebagai berikut:

$$
\gamma=\beta_{0}+\beta_{1} X_{1}+\beta_{2} X_{2}+\cdots+\beta_{n} X_{n}+\varepsilon
$$

Model regresi linear berganda untuk populasi diatas dapat ditaksir dengan persamaan 1.

2. Melakukan Pengujian Hipotesis

a. Uji Serentak (Uji F)

Digunakan untuk mengetahui hubungan antara variabel independen dan variabel dependen.

Menentukan formulasi hipotesis

(i). $H_{0}: \beta_{1}=\beta_{2}=\beta_{3}=0$, artinya variabel-variabel independen $X_{1}, X_{2}, X_{3}$, tidak mempunyai pengaruh yang signifikan secara simultan terhadap variabel dependen.

(ii). $H_{1}$ :minimal terdapat $\beta_{i} \neq 0, i=$ $0,1,2,3$, artinya variabel-variabel independen $X_{1}, X_{2}, X_{3}$, mempunyai pengaruh yang signifikan secara simultan terhadap variabel dependen.

b. Menentukan derajat kepercayaan $95 \%(a=0,05)$

c. Menentukan signifikansi

(i). Nilai signifikansi ( $\mathrm{P}$ value) $>$ 0,05 maka $H_{0}$ ditolak dan $H_{1}$ diterima.

(ii). Nilai signifikansi ( $\mathrm{P}$ value) < 0,05 maka $H_{0}$ diterima dan $H_{1}$ ditolak.

d. Membuat kesimpulan

(i). Bila $(\mathrm{P}$ value $)>0,05$ maka $H_{0}$ ditolak dan $H_{1}$ diterima. Artinya variabel independen secara simultan (bersamasama) mempengaruhi variabel dependen.

(ii). Bila (P value $)<0,05$ maka $H_{0}$ diterima dan $H_{1}$ ditolak. Artinya variabel dependen secara simultan (bersamasama) tidak mempengaruhi variabel dependen.

\section{e. Uji Parsial (Uji t)}

Digunakan untuk menguji ada atau tidaknya hubungan variabel-variabel independen.

a. Menentukan formulasi hipotesis

(i). $H_{0}: \beta_{1}=\beta_{2}=\beta_{3}=0$, artinya variabel-variabel independen $X_{1}, X_{2}, X_{3}$ tidak mempunyai pengaruh yang signifikan secara parsial terhadap variabel dependen.

(ii). $H_{1}: \beta_{i} \neq 0, i=0,1,2,3, \quad$ artinya variabel-variabel independen $X_{1}, X_{2}, X_{3}$ mempunyai pengaruh yang signifikan secara parsial terhadap variabel dependen

b. Menentukan derajat kepercayaan $95 \%(a=0,05)$

c. Menentukan signifikansi

(i). Nilai signifikansi ( $\mathrm{P}$ value) $>$ 0,05 maka $H_{0}$ ditolak dan $H_{1}$ diterima. 
(ii). Nilai signifikansi ( $\mathrm{P}$ value) $<$ 0,05 maka $H_{0}$ diterima dan $H_{1}$ ditolak.

d. Membuat kesimpulan

(i). Bila $(\mathrm{P}$ value $)>0,05$ maka $H_{0}$ ditolak dan $H_{1}$ diterima. Artinya variabel independen secara parsial mempengaruhi variabel dependen.

(ii). Bila $(\mathrm{P}$ value $)<0,05$ maka $H_{0}$ diterima dan $H_{1}$ ditolak. Artinya variabel dependen secara parsial tidak mempengaruhi variabel dependen.

3. Mencari model terbaik.

4. Melakukan Uji Asumsi Klasik yang meliputi :
a. Uji Normalitas
b. Uji Multikolinearitas
c. Uji Heteroskedastisitas
d. Uji Autokorelasi

5. Menghitung koefisien determinasi $\left(R^{2}\right)$

Nilai koefisien determinasi adalah antara 0 dan $1\left(0<R^{2}<1\right)$

6. Menginterpretasi hasil yang telah diolah dengan menyimpulkan hasil dari

langkah-langkah yang telah ditentukan.

\section{HASIL DAN PEMBAHASAN}

Data yang digunakan pada penelitian ini adalah data Jumlah Penduduk Miskin (Y), Indeks Pembangunan Manusia (X1), Jumlah Pengangguran (X2), dan Jumlah Penduduk (X3) di provinsi Sulawesi Selatan.

Tabel 3.1 Data Penelitian

\begin{tabular}{ccccc}
\hline Kab/Kota & Y & X1 & X2 & X3 \\
\hline Selayar & 17,36 & 66,91 & 1,17 & 135,6 \\
Bulukumba & 30,49 & 68,28 & 3,31 & 420,6 \\
Bantaeng & 16,91 & 68,30 & 3,98 & 187,6 \\
Jeneponto & 54,05 & 64,00 & 2,12 & 363,8 \\
Takalar & 25,93 & 66,94 & 4,13 & 298,7 \\
Gowa & 57,99 & 69,66 & 4,87 & 772,7 \\
Sinjai & 22,27 & 67,05 & 2,28 & 244,1 \\
Maros & 34,85 & 69,50 & 4,71 & 353,1 \\
Pangkep & 47,07 & 68,29 & 5,41 & 335,5 \\
Barru & 14,92 & 70,60 & 5,79 & 174,3 \\
Bone & 76,25 & 65,67 & 3,25 & 758,6
\end{tabular}

\begin{tabular}{ccccc}
\hline Kab/Kota & $\mathbf{Y}$ & $\mathbf{X 1}$ & $\mathbf{X 2}$ & $\mathbf{X 3}$ \\
\hline Soppeng & 16,45 & 68,26 & 3,53 & 227,0 \\
Wajo & 27,48 & 69,05 & 3,30 & 397,8 \\
Sidrap & 14,44 & 71,05 & 4,75 & 302,0 \\
Pingrang & 31,85 & 71,12 & 3,11 & 377,1 \\
Enrekang & 25,40 & 72,66 & 2,40 & 206,4 \\
Luwu & 46,18 & 70,39 & 4,66 & 362,0 \\
Tana Toraja & 28,87 & 68,25 & 2,74 & 234,0 \\
Luwu Utara & 42,48 & 69,46 & 3,04 & 312,9 \\
Luwu Timur & 20,83 & 72,80 & 4,08 & 299,7 \\
Toraja Utara & 28,64 & 69,23 & 3,00 & 231,2 \\
Makassar & 65,12 & 82,25 & 10,39 & 1526,7 \\
Pare-pare & 7,62 & 77,62 & 6,42 & 145,2 \\
Palopo & 14,37 & 77,98 & 10,32 & 184,6 \\
\hline
\end{tabular}

Tabel 3.1 memberikan suatu gambaran tentang Jumlah Penduduk Miskin (Y) di Sulawesi Selatan terbesar terjadi di Kota Makassar yaitu 65.12\%. Indeks Pembangunan Manusia (X1) terbesar terjadi di Kota Makkassar yaitu $82.25 \%$. sedangkan untuk Pengangguran Terbuka (X2) terjadi di Kota Makkassar yaitu $10.39 \%$ dan terendah di Kepulauan Selayar yaitu $1.17 \%$ dan Jumlah Penduduk (X3) yang terbanyak terdapat di Kota Makkassar $1526.7 \%$

Untuk melihat karakteristik dari masing-masing variabel maka ditampilkan statistik deskriptif.

Tabel 3.2 Statistik Deskriptif

\begin{tabular}{lllll}
\hline & $Y$ & $X 1$ & $X 2$ & $X 3$ \\
\hline Min & 7,62 & 64,00 & 1,170 & 135,6 \\
$\max$ & 76,25 & 82,25 & 10,39 & 1526,7 \\
Median & 28,06 & 69,34 & 3,755 & 300,9 \\
mean & 31,99 & 70,22 & 4,282 & 368,8 \\
\hline
\end{tabular}

\section{Pendugaan Model}

Model awal yang terbentuk dari hasil analisis yaitu

$$
\begin{gathered}
\hat{y}=175,53967+2,38441 x_{1}+0,79635 x_{2} \\
+0,05553 x_{3}
\end{gathered}
$$

\section{Hasil Pengujian Serentak (Uji F)}

Berdasarkan hasil analisis diperoleh nilai p-Fvalue $=0,000<0,05$, maka $H_{0}$ diterima dan $H_{1}$ di tolak. Artinya Indeks Pembangunan Manusia (X1), Pengangguran (X2), Jumlah Penduduk (X3) secara simultan (bersama-sama) 
berpengaruh signifikan terhadap variabel Jumlah Penduduk Miskin (Y).

\section{Hasil Uji Parsial (Uji t)}

Berdasarkan analisis diperoleh bahwa

a) Untuk variabel indeks pembangunan manusia (X1) diperoleh nilai p-value sebesar 0,00371 $<0,05$ yang berarti $H_{0}$ diterima. Sehingga dapat ditarik kesimpulan bahwa variabel indeks Pembangunan Manusia (X1) signifikan berpengaruh terhadap variabel Jumlah Penduduk Miskin (Y).

b) Untuk variabel Pengangguran (X2) diperoleh nilai $\mathrm{p}$-value sebesar 0,62092 >0,05 yang berarti $H_{0}$ gagal diterima. Sehingga dapat ditarik kesimpulan bahwa variabel Pengangguran (X2) tidak signifikan berpengaruh terhadap variabel Jumlah Penduduk Miskin (Y).

c) Untuk variabel Jumlah Penduduk (X3) diperoleh nilai $\mathrm{p}$-value sebesar $0,000<0,05$ yang berarti $H_{0}$ diterima. Sehingga dapat ditarik kesimpulan bahwa Jumlah Penduduk (X3) signifikan berpengaruh terhadap variabel Jumlah Penduduk Miskin (Y).

\section{Pemilihan Model Terbaik}

Dari hasil analisis, variabel yang tidak memenuhi kriteria atau tidak signifikan adalah Pengangguran (X2), sehingga variabel tersebut dikeluarkan dari model. Maka variabel yang tersisa adalah variabel Indeks Pembangunan Manusia (X1) dan Variabel Jumlah Penduduk (X3). Jadi dapat disimpulkan bahwa variabel Indeks Pembangunan Manusia (X1) dan Variabel Jumlah Penduduk (X3) berpengaruh secara signifikan dan merupakan model terbaik terhadap Jumlah Penduduk Miskin. Sehingga model regresi yang terbentuk adalah

$$
\hat{y}=155,36714-2,05362 X_{1}+0,05649 X_{3}
$$

Dari persamaan regresi diatas dapat dijelaskan sebagai berikut:

1. Nilai konstanta sebesar 155.36714. Artinya apabila variabel Indeks Pembangunan Manusia (X1) dan variabel Jumlah Penduduk (X3) diasumsikan constant maka diperkirakan rasio jumlah penduduk miskin sebesar 155 jiwa/orang dalam setahun.

2. Variabel Indeks Pembangunan Manusia (X1) berpengaruh negatif dan variabel Jumlah Penduduk (X3) berpengaruh positif terhadap jumlah penduduk miskin (Y).

\section{Uji Normalitas}

Berdasarkan analisis diperoleh hasil uji Shapiro-Wilk dengan nilai p-value yaitu 0,03915 dimana nilainya lebih kecil 0,05 sehingga $H_{0}$ diterima dan $H_{1}$ ditolak artinya data berdistribusi normal.

\section{Uji Multikolinearitas}

Berdasarkan analisis diperoleh nilai Variance Inflation Factor (VIF) untuk variabel indikator Indeks Pembangunan Manusia (X1) sebesar 1,170325, dan Variance Inflation Factor (VIF) untuk variabel Jumlah Penduduk (X3) sebesar 1,170325. Sehingga dapat dilihat semua nilai variance inflation factor (VIF) $<10$ maka $H_{0}$ diterima dan $H_{1}$ ditolak, artinya tidak terjadi multikolinearitas.

\section{Uji Heteroskedastisitas}

Berdasarkan hasil analisis dengan uji Breusch-Pagan diperoleh nilai $\mathrm{p}$-value $=0,7137$ $>0,05$ maka $H_{0}$ diterima dan $H_{1}$ ditolak, artinya tidak terdapat heteroskedastisitas.

\section{Uji Autokorelasi}

Berdasarkan hasil analisis diperoleh nilai Durbin-Watson sebesar 1,9866 yang berarti nilainya lebih besar dari $d u$ yaitu 1,546 dan lebih kecil dari 4-du yaitu 2,454 sehingga dapat disimpulkan $H_{0}$ diterima dan $H_{1}$ ditolak, artinya tidak terdapat autokorelasi.

\section{Koefisien Determinasi}

Berdasarkan pemilihan model terbaik diperoleh nilai koefisien determinasi $\left(R^{2}\right)$ sebesar $75,63 \%$, artinya pengaruh variabel Indeks Pembangunan Manusia (X1) dan Jumlah Penduduk (X3) terhadap Jumlah Penduduk Miskin (Y) sebesar 75,63\%. 


\section{KESIMPULAN}

Berdasarkan hasil penelitian maka kesimpulan yang dapat diambil adalah Indeks Pembangunan Manusia (X1) berpengaruh negatif terhadap Jumlah Penduduk Miskin (Y), jumlah pengangguran (X2) tidak berpengaruh terhadap Penduduk Miskin (Y), dan Jumlah Penduduk (X3) berpengaruh positif terhadap Penduduk Miskin (Y). Berdasarkan model terbaik diperoleh

a. nilai koefisien determinasi $\left(R^{2}\right)$ sebesar $75,63 \%$, artinya pengaruh variabel Indeks Pembangunan Manusia (X1) dan Jumlah Penduduk (X3) terhadap Jumlah Penduduk Miskin (Y) sebesar 75,63\%.

b. nilai konstanta sebesar 155,36714 , artinya apabila variabel Indeks Pembangunan Manusia (X1) dan variabel Jumlah Penduduk (X3) diasumsikan konstan maka diperkirakan rasio Jumlah Penduduk Miskin (Y) sebesar 155 jiwa/orang.

\section{DAFTAR PUSTAKA}

[1] Hudaya, dkk. 2009. "Faktor - Faktor Yang Mempengaruhi Tingkat Kemiskinan Di Indonesia”. IPB Universty: Scientific Repository.

[2] A Rivandi, dkk. 2019. "Penerapan Metode Regresi Linier Berganda Dalam Estimasi Biaya Pencetakan Spanduk (Studi Kasus: PT. Hansindo Setiapratama)". Jurnal Pelita informatika, Vol 7, No. 3, Jan 2019, hal;263-268

[3] M Mona, dkk. 2016. Penggunaan Regresi Linear Berganda untuk Menganalisis Pendapatan Petani Kelapa Studi Kasus: Petani Kelapa Di Desa Beo, Kecamatan Beo Kabupaten Talaud. Jurnal d'Cartesian: Jurnal Matematika dan Aplikasi, Vol 4, No.2 (2015)

[4] Yan, S \& Su, XG. 2009."Linear Regression Analysis: Theory and Computing". USA: World Scientific Publishing Co. Pte. Ltd

[5] Montgomery DC, dkk. 2012."Intoduction to Linear Regression Analysis: Theory and Computing". Canada. John Wiley \& Soms. Inc
[6] Suyono. 2016. Analisis Regresi Untuk Penelitian. Yogyakarta: deepublish

[7] Sulistyono \& W Sulistiyowati. Peramalan Produksi dengan Metode Regresi Linier Berganda. Jurnal Prozima, Vol 1, No.2, December 2017, hal.82-89 